Violence

\section{Violence against women: a global public health issue!}

\section{G Krantz}

\section{Violence against women has an effect on public health}

V iolence against women is a significant health and social problem affecting virtually all societies, but often it goes unrecognised and unreported and in many countries it is still accepted as part of normal behaviour. ${ }^{1}$ The manifestations and forms of violence vary in different settings, but most of the violence against women takes place within families and the perpetrators are almost exclusively men who are or have been in a close relationship with the woman. ${ }^{2}$

Although reliable data on the prevalence of violence against women by their partners are scarce, especially in developing countries, a growing body of research confirms its existence. Forty population based quantitative studies conducted in 24 countries on four continents revealed that between $20 \%$ and $50 \%$ of the women interviewed reported that they had suffered physical violence from their male partner. ${ }^{2}$ In surveys of community based populations, students and primary care patients in industrialised countries, about $5 \%-62 \%$ of the participating women had a history of childhood sexual abuse. ${ }^{3}$ In a random sample of Swedish women, 40 to 50 years of age, $32 \%$ disclosed having suffered violence or abuse during childhood and 15\% reported such experience as adults. ${ }^{4}$ Studies from Malaysia, India, and the Republic of Korea report that $22 \%-42 \%$ of the women interviewed had been physically assaulted by their husband. ${ }^{2}$ Worldwide it has been estimated that violence against women is as serious a cause of death and incapacity among women of reproductive age as cancer, and a greater cause of ill health than traffic accidents and malaria combined. ${ }^{5}$ When comparing the industrial with the developing world, the burden of disease imposed by rape and domestic violence seems to be roughly equivalent on a per capita basis. ${ }^{2}$

Gender based violence defines violence that is directed against a woman because she is a woman or that affects women disproportionately. It includes acts that inflict physical, mental or sexual harm or suffering, threats of such acts, coercion, and other deprivations of liberty. ${ }^{6}$ Gender based violence includes domestic violence, forced sex and other forms of sexual violence, trafficking in women as well as country specific forms, such as dowry related deaths and female genital mutilation. ${ }^{7}$ It occurs in different locations and situations, such as in the home, in prisons, in the community, in situations of armed conflict, refugee and displacement. In all of these situations gender power differentials and other inequalities play an important part and women are particularly exposed to these forms of violence. ${ }^{8}$

Violence against women affects all spheres of a woman's life-her autonomy, her productivity, and her capacity to care for herself and her children and subsequently also her overall health status and quality of life. Women who have suffered violence or abuse are much more likely to report somatic symptoms related to panic, depression, musculoskeletal disorders and chronic pain, genitourinary disorders, and respiratory illness. ' Furthermore, women with such experience are more likely to misuse drugs and to attempt suicide. ${ }^{10}$ The health sector has an important part to play, as women are regular visitors and frequently turn to it despite its poor record in most settings of providing sensitive care to victimised women. Health care staff, well trained in how to meet women exposed to violence, is a prerequisite for in the first place to dare inquire about such experience but also to be able to offer appropriate treatment and support.

However, gender based violence is not only a health problem of the individual. A public health approach is needed to tackle gender violence in both industrialised and in low income countries. To tackle violence requires collaboration between many sectors, such as education, health, police, social and legal authorities, the church, and nongovernmental organisations (NGO) to find preventive measures and, for as long as gender violence cannot be prevented, also to provide care for women experiencing abuse, and their children. Support to victimised women needs to be easily accessible at the local level as counselling, self help support groups and women's shelters.
Violence against women is more than a health issue; it is also a violation of women's human rights, their bodily integrity, and their sexual and reproductive rights. The United Nations' Convention on the Elimination of All Forms of Discrimination against Women (CEDAW) was adopted in 1978. The Convention encompasses all rightscivil, political, economic, social, and cultural-and as such it is a comprehensive treaty on women's human rights that lays down governmental obligations corresponding to individual rights and freedom. ${ }^{6}$ In this way pointing at gender based violence as a political issue contributes to viewing it not mainly as a cultural, private or individual issue but as a political matter that will require states to take action.

Violence against women also has a profound impact on development. It perpetuates poverty by reducing women's capacity to work outside the home, their mobility and access to information, and children's school attendance.

The "right to development" was introduced in the Banjul charter. ${ }^{11}$ The idea is that the economic development of the poorer countries of the world is essential to their social wellbeing and political stability and that without it, they would be in no position to guarantee the civil, political, economic, social, and cultural rights prescribed in major international documents. The significance of women's health and socioeconomic wellbeing is increasingly recognised and seen as a necessity for a sustainable development and it is now recognised that women constitute a major force for change. Gender based violence, however, is a major constraint to women's full participation in society.

The UN conference on HIV/AIDS held in June 2001 adopted a declaration stating that in the year 2005 all women in all member states should have the right to decide about their own sexuality. This is an important statement if it also requires states to take action not only on how to turn women into decision makers, but also on the male gender role and responsibilities. So far, the main focus in research as well as in projects and programmes has been on the woman, her economic situation, her coping strategies and on how to treat and protect women. Much less emphasis has been put on the male role, masculinity or rather masculinities, and why men exercise violence against someone whom they are in a close relationship with.

So research within this field needs to go on, continuing to improve knowledge on violence against women, gender roles and their interplay, but also on the role of the state, where for instance the degree of protection offered by the law seems to have preventive implications. In this issue of JECH there is an article on 
sexual assault among women in North Carolina where women in a household telephone survey reported a lifetime prevalence of sexual assault of $19 \%{ }^{12}$ The authors further investigated metabolic effects in the women exposed to violence and made some interesting findings.

$J$ Epidemiol Community Health 2002; 56:242-243

\section{Author's affiliation}

G Krantz, Nordic School of Public Health, Box 121 33, SE-402 42 Göteborg, Sweden

Correspondence to: $\mathrm{Dr} G$ Krantz; gunillak@nhv.se or gunillakrantz@hotmail.com

\section{REFERENCES}

1 Heise LL, Raikes A, Watts $\mathrm{CH}$, et al. Violence against women: a neglected public health issue in less developed countries. Soc Sci Med 1994;39:1165-79.
2 Heise LL, Pitanguy J, Germain A. Violence against women: the hidden health burden. Washington DC: World Bank, 1994.

3 Mc Cauley J, Kern DE, Kolodner K, et al. Relation of low severity violence to women's health. J Gen Intern Med 1998;13:697-91

4 Krantz G, Östergren P-O. The association between violence victimisation and common symptoms in Swedish women. J Epidemiol Community Health 2000;54:815-21.

5 World Bank. World Development Report 1993. Investing in health. New York: Oxford University Press, 1993.

6 Mann J, Gruskin S. Women's health and human rights: genesis of the health and human rights movement. In: Gruskin S, ed. Health and Human rights - an international quaterly journal. Cambridge: Harvard School of Public Health, 1995;1:309-12

7 Garcia-Moreno C. Violence against women, gender and health equity. Harvard Center for population and development studies, working paper series number 99.15. Cambridge: Harvard School of Public Health, 1999

8 Ellsberg $M$, Pena R, Herrera A, et al. Wife abuse among women of childbearing age in Nicaragua. Am J Public Health 1999;89:241-4.

9 Leserman J, Li Z, Drossman DA, et al. Selected symptoms associated with sexual and physical abuse history among female patients with gastrointestinal disorders: the impact on subsequent health care visits. Psychol Med 1998;28:417-25.

10 McCauley J, Kern DE, Kolodner K, et al. Clinical characteristics of women with a history of childhood abuse: unhealed wounds. JAMA 1997;227:1362-8.

11 Richters JMA. Women, culture and violence. A development, health and human rights issue. Leiden: Women and Autonomy Centre (VENA), 1994.

12 Cloutier S, Martin SL, Poole C. Sexual assault among North Carolina women: prevalence and health risk factors. J Epidemiol Community Health 2002:56:265-71.

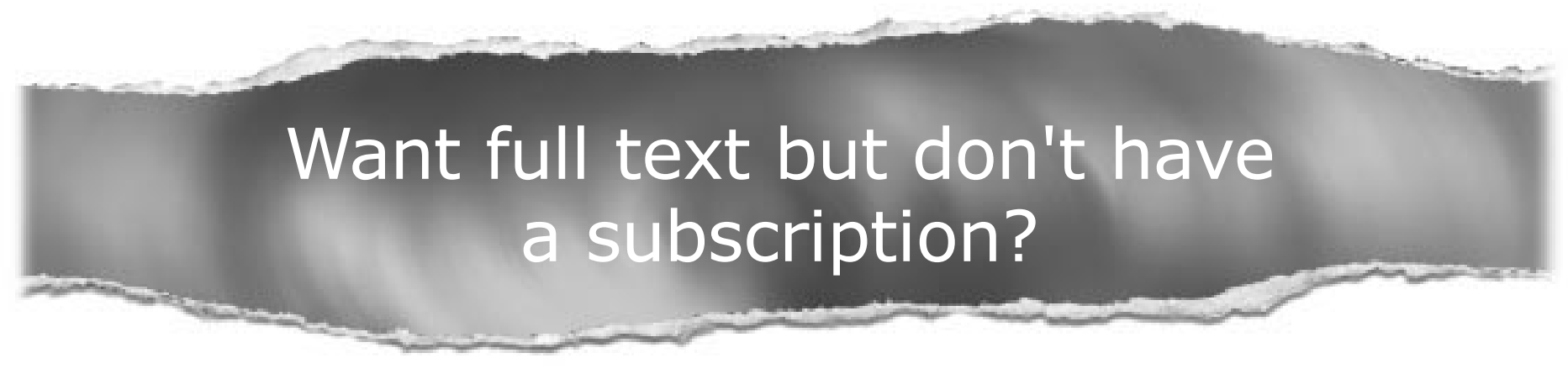

\section{Pay per view}

For just $\$ 8$ you can purchase the full text of individual articles using our secure online ordering service. You will have access to the full text of the relevant article for 48 hours during which time you may download and print the pdf file for personal use.

www.jech.com 